HORTSCIENCE 27(10):1127-1129. 1992

\title{
Use of a Cytokinin Conjugate for Efficient Shoot Regeneration from Leaf Sections of Highbush Blueberry
}

\author{
Lisa J. Rowland and Elizabeth L. Ogden \\ Fruit Laboratory, Beltsville Agricultural Research Center, Agricultural \\ Research Service, Beltsville, MD 20705
}

Additional index words. zeatin riboside, in vitro, propagation, tissue culture, Vaccinium corymbosum

\begin{abstract}
Conditions for improving the efficiency of shoot regeneration from leaf sections of highbush blueberry (Vaccinium corymbosum L.) were investigated. Effectiveness of tissue culture medium supplemented with the cytokinin conjugate zeatin riboside or the cytokinin zeatin at 10,20 , or $30 \mu \mathrm{M}$ was compared with medium supplemented with the optimum $2 \mathrm{iP}$ concentration of $15 \mu \mathrm{M}$. Use of $20 \mu \mathrm{M}$ zeatin riboside resulted in the most shoots per leaf section, » 6-fold higher than the number of shoots produced on 2iP medium. The number of shoots produced on medium supplemented with zeatin was not significantly higher than the number of shoots produced on $2 \mathrm{iP}$ medium. Consequently, we concluded that the cytokinin conjugate zeatin riboside was more effective than either of the free cytokinins, $2 \mathrm{iP}$ or zeatin, in promoting shoot regeneration from leaf sections of highbush blueberry. Chemical names used: 6-(y,y-dimethylallylamino)-purine (2iP); 6-(4-hydroxy-3-methyl-but-2-enylamino)purine (zeatin).
\end{abstract}

Interest in producing transgenic blueberry plants using an engineered strain of Agro bacterium tumefaciens has prompted us to investigate ways of improving the efficiency of shoot regeneration from leaf sections. The number of transformed cells recovered after inoculation with Agrobactetium is proportional to the number of cells capable of regenerating shoots. Therefore, production of many shoots per leaf section is critical.

Several laboratories have reported the ability to regenerate shoots from leaf sections of cultivated highbush blueberry (Billings et al., 1988; Callow et al., 1989; Dweikat and Lyrene, 1988). Callow et al. (1989) examined shoot regeneration from leaf sections

Received for publication 2 Jan. 1992. Accepted for publication 28 May 1992. The cost of publishing this paper was defrayed in part by the payment of page charges. Under postal regulations, this paper therefore must be hereby marked $a d$ vertisement solely to indicate this fact. of 'Bluecrop' blueberry on tissue culture medium supplemented with $5,25,50$, or 100 $\mu \mathrm{M} 2 \mathrm{iP}$ and reported the greatest number of meristematic nodules and buds per leaf were induced at $25 \mu \mathrm{M}$. They also reported the ability to produce shoots from leaf explants of 'Bluejay' and 'Jersey' blueberries on medium supplemented with 5 to $25 \mu \mathrm{M} 2 \mathrm{iP}$. Billings et al. (1988) examined shoot regeneration from leaf sections of 'Berkeley' and 'Bluehaven' blueberries on medium containing $0,5,10,15$, or $20 \mu \mathrm{M} 2 \mathrm{iP}$ and found the optimal $2 \mathrm{iP}$ concentration for shoot regeneration was $15 \mu \mathrm{M}$.

Medium containing the cytokinin conjugate zeatin riboside has been reported to be superior to cytokinins for shoot regeneration from leaf explants of tomato (Tatchell and Binns, 1986) and potato (Sheerman and Bevan, 1988). The effectiveness of conjugates of plant growth regulators is apparently due to the slow, steady release of free growth regulator from the medium (Hangarter et al., 


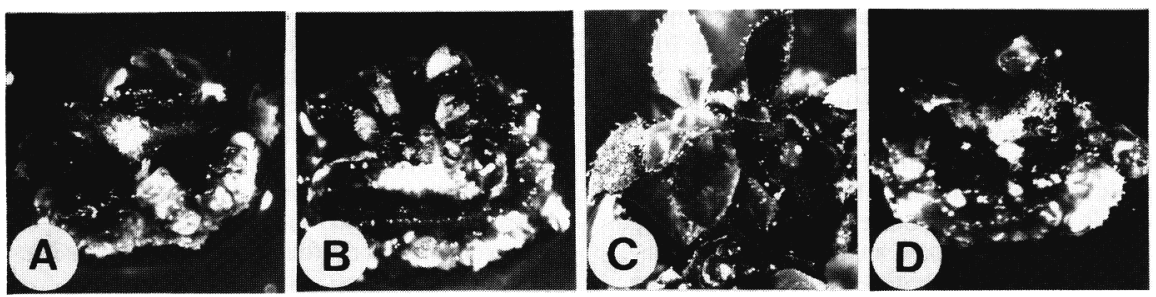

Fig. 1. Representative leaf sections of 'Sunrise' blueberry on shoot regeneration medium containing $15 \mu \mathrm{M} 2 \mathrm{iP}$ (A) and 10, 20, or $30 \mu \mathrm{M}$ zeatin riboside (B-D, respectively). Photographs were taken after 11 weeks in culture.

Table 1. Comparison of $2 \mathrm{iP}$ and zeatin riboside (ZR) for effectiveness in promoting shoot regeneration from leaf sections of 'Sunrise' blueberry.

\begin{tabular}{lccccc}
\hline \hline Cytokinin & $\begin{array}{c}\text { Concn } \\
(\mu \mathrm{M})\end{array}$ & $\begin{array}{c}\text { Live sections } \\
\text { at 13 weeks } \\
(\text { no. })\end{array}$ & $\begin{array}{c}\text { Buds/live } \\
\text { section } \\
\text { (no.) }\end{array}$ & $\begin{array}{c}\text { Shoots/live } \\
\text { section } \\
\text { (no.) }\end{array}$ & $\begin{array}{c}\text { Shoot length } \\
(\mathrm{mm})\end{array}$ \\
\hline 2iP & 15 & 22 & $7.1 \mathrm{~b}^{\mathbf{x}}$ & $3.7 \mathrm{~b}$ & $1.3 \mathrm{~b}$ \\
$\mathrm{ZR}$ & 10 & 18 & $5.1 \mathrm{~b}$ & $6.1 \mathrm{~b}$ & $2.6 \mathrm{a}$ \\
& 20 & 22 & $18.1 \mathrm{a}$ & $20.8 \mathrm{a}$ & $2.6 \mathrm{a}$ \\
& 30 & 22 & $17.6 \mathrm{a}$ & $8.8 \mathrm{~b}$ & $1.4 \mathrm{~b}$ \\
\hline
\end{tabular}

${ }^{\mathrm{z}} \mathrm{LSD}_{0.05}$ value for number of buds was 6.39. $\mathrm{LSD}_{0.05}$ values for the transformed data, square root of number of shoots and log of shoot length, were 1.35 and 0.17 , respectively.

yMeans were back-transformed.

Mean separation within columns by LSD, $P=0.05$.

Table 2. Comparison of $2 \mathrm{iP}$ and zeatin for effectiveness in promoting shoot regeneration from leaf sections of 'Sunrise' blueberry.

\begin{tabular}{lccccc}
\hline \hline Cytokinin & $\begin{array}{c}\text { Concn } \\
(\mu \mathrm{M})\end{array}$ & $\begin{array}{c}\text { Live sections } \\
\text { at 13 weeks } \\
\text { (no.) }\end{array}$ & $\begin{array}{c}\text { Buds/live } \\
\text { section } \\
(\text { no.) }\end{array}$ & $\begin{array}{c}\text { Shoots/live } \\
\text { section }^{\mathrm{y}} \\
\text { (no.) }\end{array}$ & $\begin{array}{c}\text { Shoot length } \\
(\mathrm{mm})\end{array}$ \\
\hline 2iP & 15 & 13 & $19.1 \mathrm{a}^{\mathbf{x}}$ & $3.1 \mathrm{a}$ & $1.2 \mathrm{~b}$ \\
Zeatin & 10 & 11 & $25.9 \mathrm{a}$ & $7.8 \mathrm{a}$ & $2.8 \mathrm{a}$ \\
& 20 & 19 & $28.1 \mathrm{a}$ & $11.8 \mathrm{a}$ & $2.3 \mathrm{a}$ \\
& 30 & 16 & $34.1 \mathrm{a}$ & $12.9 \mathrm{a}$ & $2.5 \mathrm{a}$ \\
\hline
\end{tabular}

${ }^{z} \mathrm{LSD}_{0.05}$ value for number of buds was 15.65. $\mathrm{LSD}_{0.05}$ values for the transformed data, square root of number of shoots and log of shoot length, were 1.97 and 0.21 , respectively.

y Means were back-transformed.

xMean separation within columns by LSD, $P=0.05$.

1980). We present a comparison of shoot regeneration from leaf explants of three highbush blueberry varieties on medium containing the determined optimal $2 \mathrm{iP}$ concentration of $15 \mu \mathrm{M}$ (Billings et al., 1988) and on medium containing zeatin riboside at 10,20 , or $30 \mu \mathrm{M}$. Results from a later comparison of shoot regeneration on medium containing $2 \mathrm{iP}$ and zeatin are also presented.

Leaves for these experiments were collected from established tissue cultures of 'Bluecrop', 'Duke', and 'Sunrise'. They were established from shoot explants by growing cultures at $23 \mathrm{C}$ for a 16 -h photoperiod (40 to $\left.45 \mu \mathrm{mol} \cdot \mathrm{m}^{-2} \cdot \mathrm{s}^{-1}\right)$ on woody plant medium (WPM) (Lloyd and McCown, 1980) modified as follows $\left(\mathrm{mg} \cdot \mathrm{liter}^{-1}\right): 684$ $\mathrm{Ca}\left(\mathrm{N} \mathrm{O}_{3}\right)_{2} \cdot 4 \mathrm{H}_{2} \mathrm{O}, 190 \mathrm{~K} \mathrm{~N} 0_{3}, 73.4$ $\mathrm{C}_{10} \mathrm{H}_{13} \mathrm{FeN}_{2} \mathrm{NaO}_{8}$, and 0.1 thiamine $\mathrm{HCl}$. Not included were $\mathrm{K}_{2} \mathrm{SO}_{4}, \mathrm{CaCl}_{1}, \mathrm{FeSO}_{4}$, and $\mathrm{Na}_{2}$ EDTA, Medium also contained $0.5 \%$ sucrose, $0.55 \%$ agar, $24.6 \mu \mathrm{M} 2 \mathrm{iP}$, and 9.12 $\mu \mathrm{M}$ zeatin. The final $\mathrm{pH}$ was adjusted to 5.2. Explants were prepared from tissue-cultured leaves by cutting perpendicular to the midrib to remove apical and basal portions of the leaf. The remaining central portions of the leaves were then placed abaxial side up on the surface of shoot regeneration medium in $100 \times 15-\mathrm{mm}$ petri plates.
To verify the optimum $2 \mathrm{iP}$ concentration for subsequent comparisons to zeatin and zeatin riboside, a preliminary experiment was performed in which shoot regeneration of 'Sunrise' was compared on medium supplemented with three concentrations of 2iP. Shoot regeneration medium consisted of WPM modified as described above, $2 \%$ sucrose, $0.55 \%$ agar, $\mathrm{pH} 5.2$, and $2 \mathrm{iP}$ concentrations of 5,15 , or $25 \mu \mathrm{M}$. Twenty leaf sections were placed on medium containing each concentration of $2 \mathrm{iP}$. Use of $15 \mu \mathrm{M} 2 \mathrm{iP}$ resulted in the most shoots per section-4.7 and 3.5 times higher than the number of shoots per section produced on $5 \mu \mathrm{M} 2 \mathrm{iP}$ and on 25 $\mu \mathrm{M} 2 \mathrm{iP}$, respectively.

Shoot regeneration was then compared on medium supplemented with $15 \mu \mathrm{M} 2 \mathrm{iP}$ and 10,20 , or $30 \mu \mathrm{m}$ zeatin riboside. Five plates were prepared per cytokinin concentration for each variety. Each petri plate contained five leaf sections for a total of 25 sections per treatment for each variety. Petri plates were placed in the dark for 1 week at $23 \mathrm{C}$ and then provided with a $16-\mathrm{h}$ photoperiod (20 to $25 \mu \mathrm{mol} \cdot \mathrm{m}^{-2} \cdot \mathrm{s}^{-1}$ at $23 \mathrm{C}$ for the remaining time in culture. The number of regenerating leaf sections and buds per leaf section were determined after 5 weeks in culture. After 7 weeks in culture, all explants were trans- ferred to modified WPM with $2 \%$ sucrose, $24.6 \mu \mathrm{M} 2 \mathrm{iP}$, and $9.12 \mu \mathrm{M}$ zeatin. After 13 weeks in culture, regenerated shoots were excised and counted. Shoots were also measured and the mean shoot length calculated for each leaf section.

To determine if differences in the efficiency of shoot regeneration on medium containing zeatin riboside vs. $2 \mathrm{iP}$ were due to the presence of a different cytokinin (zeatin rather than $2 \mathrm{iP}$ ) or to the presence of a cytokinin conjugate rather than a free form of cytokinin, regeneration was also compared on medium containing $15 \mu \mathrm{M} 2 \mathrm{iP}$ and 10,20 , or $30 \mu \mathrm{M}$ zeatin. This comparison was identical to the previous one, with the exception that a total of 20 leaf explants per variety rather than 25 was tested at each of the four cytokinin concentrations.

In the comparisons of $2 \mathrm{iP}$ with zeatin and zeatin riboside, the mean number of buds per surviving section, number of shoots per surviving section, and shoot length were calculated for each plate. Data were subjected to an analysis of variance (ANOVA) after testing the assumptions of variance homogeneity and normality and transforming data as necessary to conform to assumptions. Transformation was necessary for number of shoots (square root) and for shoot length ( $\log$ ) but not for number of buds. The analysis was run as a one-way, completely randomized design with four or five plate replicates per treatment, depending on the experiment. When the ANOVA indicated that significant differences existed between treatment means, the least significant difference test $(P=0.05)$ was performed.

From the comparison of $2 \mathrm{iP}$ with zeatin riboside, we noted that 'Sunrise' exhibited excellent regeneration ability (Table 1), producing several shoots per section, whereas 'Duke' and 'Bluecrop' produced no shoots on any of the media tested (data not shown). Representative leaf sections of 'Sunrise' after 11 weeks in culture and started on medium containing $15 \mu \mathrm{M} 2 \mathrm{iP}$ or 10,20 , or $30 \mu \mathrm{M}$ zeatin riboside are shown in Fig. 1. Leaf sections on medium supplemented with 20 or $30 \mu \mathrm{M}$ zeatin riboside produced the most buds per surviving section after 5 weeks in culture, which was significantly higher than for leaf sections on medium supplemented with either $2 \mathrm{iP}$ or $10 \mu \mathrm{M}$ zeatin riboside (Table 1). After 13 weeks in culture, buds had developed into shoots and had elongated sufficiently to count. Leaf sections started on medium containing $20 \mu \mathrm{m}$ zeatin riboside produced significantly more shoots than did all the other sections. Mean number of shoots per surviving section was 5.6 times higher on medium supplemented with $20 \mu \mathrm{M}$ zeatin riboside than on medium supplemented with 2iP. Also, shoots were about twice as long on medium supplemented with $20 \mu \mathrm{M}$ zeatin riboside than on $2 \mathrm{iP}$ medium (Table 1 ).

The comparison of $2 \mathrm{iP}$ with zeatin revealed that the number of buds and shoots per surviving section of 'Sunrise' did not differ significantly among treatments although the extreme values differed by factors of 1.8 and 4.1, respectively (Table 2). However, 
shoots on medium containing zeatin were about twice as long as those on $2 \mathrm{iP}$ medium (Table 2). Chandler and Draper (1986) have previously reported that use of zeatin increased proliferation of shoot tips two to four times more than $2 \mathrm{iP}$ in three highbush blueberry clones. Again, 'Bluecrop' and 'Duke' produced no shoots on any of the media tested. Regeneration efficiency has been found to vary among varieties of many other species; thus, finding regeneration efficiency to be genotype-dependent in blueberry is not surprising. Several of the shoots produced on zeatin and zeatin riboside media were later transferred to $50 \%$ perlite : $50 \%$ peat, where they easily rooted.

In summary, our results show first that the cytokinin conjugate zeatin riboside is more effective in promoting shoot regeneration from leaf sections of highbush blueberry than the free cytokinin 2iP. Our results also suggest that this improvement in shoot regeneration is not entirely due to the presence of a different cytokinin (zeatin vs. 2iP) but, rather, to the presence of a cytokinin conjugate vs. free cytokinin. Furthermore, although zeatin and zeatin riboside are considerably more costly than $2 \mathrm{iP}$, zeatin riboside may be well worth the additional cost under certain circumstances, specifically, Agrobacteriummediated transformations. Recently, successful use of Agrobacterium tumefaciens to transform apple (Malus domestica Borkh.) was reported (James et al., 1990). Transformation efficiency was very low; 400 leaf explants gave rise to three transgenic shoots. The average number of expected shoots per leaf explant, without selection, was six. If the number of expected shoots per explant had been, for example, 3-fold higher, then, theoretically, one-third of the leaf explants (in this case, 133 vs. 400) would have given rise to the same number of transgenic shoots. In the case of blueberry, by using zeatin riboside in the medium, we have obtained five to six times as many shoots per leaf explant as with $2 \mathrm{iP}$. Therefore, the conditions we describe are probably more suitable than use of $2 \mathrm{iP}$ for recovering transgenic shoots after inoculation of leaf sections with Agrobacterium.

\section{Literature Cited}

Billings, S.G., C.K. Chin, and G. Jelenkovic. 1988. Regeneration of blueberry plantlets from leaf segments. HortScience 23:763-766.

Callow, P., K. Haghighi, M. Giroux, and J. Hancock. 1989. In vitro shoot regeneration on leaf tissue from micropropagated highbush blueberry. HortScience 'X373-375.

Chandler, C.K. and A.D. Draper. 1986. Effect of zeatin and $2 \mathrm{iP}$ on shoot proliferation of three highbush blueberry clones in vitro. HortScience 21:1065-1066

Dweikat, I.M. and P.M. Lyrene. 1988. Adventitious shoot production from leaves of blueberry cultured in vitro. HortScience 23:629.

Hangarter, R.P., M.D. Peterson, and N.E. Good. 1980. Biological activities of indoleacetylamino acids and their use as auxins in tissue culture. Plant Physiol. 65:761-767.

James, D.J., A.J. Passey, and D.J. Barbara. 1990 Regeneration and transformation of apple and strawberry using disarmed Ti-binary vectors, $\mathrm{p}$. 239-248. In: G.W. Lycett and D. Grierson (eds.). Genetic engineering of crop plants. Courier International, Tiptree, Essex, U.K.

Lloyd, G. and B. McCown. 1980. Commercially feasible micropropagation of mountain laurel, Kalmia latifolia, by use of shoot tip culture. Proc. Intl. Plant Prop. Soc. 30:421-427.
Sheennan, S. and M.W. Bevan. 1988. A rapid transformation method for Solanum tuberosum using binary Agrobacrerium tumefaciens vectors. Plant Cell Rpts. 7:13-16.

Tatchell, S. and A.N. Binns. 1986. A modified MS media for regeneration of direct explants and long term callus cultures of tomato. Tomato Genetics Co-op Nwsl. 36:35-36. 